\title{
Creating an inclusive educational environment for vocational learning: $A$ tale of two cities
}

\author{
Darren Turnbull, Ritesh Chugh and Jo Luck \\ Central Queensland University, Australia
}

\begin{abstract}
One of the significant challenges facing vocational training institutions is the conundrum of providing the best possible learning outcomes to a diverse range of people using pedagogical practices and materials that by design demand uniformity in delivery approaches. In this paper, we examined a snapshot of perspectives from teachers and students in two distinctly different vocational training institutions, one in China and the other in Australia. Comments from participants revealed that flexible approaches to course delivery, the provision of a range of different types of learning materials, and institutional support in teacher training and curriculum design are vital elements in implementing an inclusive learning space for students. This paper proposes that a triad of interrelated elements, consisting of pedagogy, learning materials and institutions, are bound together by learning management systems that facilitate the creation of multi-modal course delivery approaches. We further contend that teaching practices that pigeonhole people as belonging to immutable categories of learning styles are outmoded and detract from creating inclusive learning environments. The findings from this study indicate that best practice approaches for developing truly engaging educational environments are rooted in the facilitation of individual autonomy in the learning process. The creation of opportunities for constructive interaction between learners is needed.
\end{abstract}

Keywords: Inclusive practice, online learning, LMS, pedagogy, learning style

\section{Introduction}

Putting learners at the centre of learning and teaching activities is a critical goal of all educational efforts. However, teachers do not create learning - instead, the students themselves are at the centre of the knowledge construction process (Levin, 2000). Furthermore, many institutions insist on perpetuating an environment where the knowledge to be learned is fixed, and the learner is a passive recipient of information that a third party must objectively measure against a set of fixed criteria. This is essentially the difference between a constructivist approach where students build their understanding of key concepts and behaviourist methodologies where knowledge acquisition is measured by objective observation (Boghossian, 2006). The purpose of this paper is to contrast the learning environments and practices of two distinctly different vocational institutions, one in Australia and the other in China, in order to identify possible enablers and inhibitors to inclusive practice in vocational education. Inclusive education is a philosophy and practice that attempts to extend learning opportunities to all students in a shared environment (Moriña, 2017). Therefore, inclusive practice in education delivery should ensure that no learner is excluded based on learning styles, culture, capabilities or gender. Moreover, learning style theories are considered to lack an explanatory framework, exhibit poor reliability and matching instruction to preconceived notions of each students' learning style is a disservice to students (An \& Carr, 2017).

Many factors influence the effective delivery of education to learners. The three most significant influences on learning outcomes are teachers' pedagogical practices, the learning materials used to support teaching, and the institution that sets the tone for the environment in which learning occurs. The intersection of these three influences encompasses online learning tools like learning management systems (LMS) that ideally should connect these elements. This is represented in Figure 1 as the learning environment trilogy (LET).

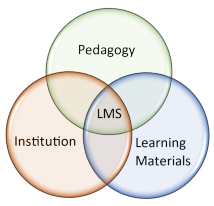

Figure 1. Learning Environment Trilogy 
Pedagogy refers to what a teacher does to enhance the learning of others (Watkins \& Mortimore, 1999). Institutions encompass all formal organisations that connect learners and teachers in the knowledge transfer process and are crucial to providing an effective learning environment (Mapuva, 2009). Importantly, institutions no longer need to maintain a physical presence: they can exist in more fluid arrangements such as complete online learning communities. The learning materials referred to in Figure 1 are those resources created to support learning activities. These resources can be represented in various forms: written, audio-visual, and physical artefacts. An essential consideration of learning material development is the intended mode of delivery, i.e., online or face-to-face (F2F). Course materials produced for a classroom environment are likely to be ineffective when delivered online (Chugh et al., 2017). The glue that binds these interrelated elements together is institutional LMSs. LMSs are web-based software platforms that facilitate online learning environments (Turnbull et al., 2019). More than simply supporting educational administration, effective LMSs must incorporate pedagogical principles in their design (Govindasamy, 2001) and support different types of course materials (Wang et al., 2013). This is crucial to the synergistic operation of the LET.

This paper outlines how pedagogy, learning materials and institutions influence inclusive learning spaces. Organising these three essential elements to deliver compelling knowledge creation opportunities that are inclusive for all individual learners is challenging. Inclusive pedagogy is an individual-focused approach to teaching and learning that recognises individual differences and avoids situations where learners are excluded because their learning styles do not fit group norms (Florian \& Spratt, 2013). In addition, an inclusive practice should also ensure that curriculum and learning materials reach out to all learners and strengthen person-toperson interactivity (Stone, 2017). This requires institutional support to entrench inclusivity into course delivery mechanisms. Institutional LMSs should facilitate the coordination of the three elements of the trilogy. However, in many cases, such systems are set up to deliver learning in a pre-determined sequence which is not ideal for all learners (Vallis \& Shalavin, 2020).

One of the issues impeding an inclusive environment is the uneven power balance of the stakeholders. Institutions usually have formal employee-employer relationships, which influence to a considerable degree how individual teachers shape their course deliveries. At the bottom of the hierarchy are students who are often regarded as passive learning elements by university administrations and teachers in some jurisdictions such as China (Chan, 2019). Preliminary data in this study indicated that institutional values and priorities could significantly influence the methods and materials used to enable course delivery.

\section{Method}

This paper presents sample comments from teachers and students that reveal how the LET model influences inclusivity in physical and online learning spaces. This project included extensive stakeholder interviews focused on LMS efficacy issues at two vocational training institutions in China and Australia (names witheld to provide anonymity). Ethics approval from Central Queensland University was received for this study. Owing to the COVID-19 pandemic, interviews $\left(\mathrm{N}_{\text {teacher }}=21, \mathrm{~N}_{\text {students }}=17\right)$ were conducted via Zoom. Each interview involved a 60-minute semi-structured conversation on LMS issues. NVivo software was used to code the interview data. The participant quotes in the discussion section are coded to preserve anonymity while indicating the role of the interviewee (teacher or student) and their affiliation (Australia or China). The included interview comments (verbatim in italics) were selected based on their relevance to the topic of inclusive practice at both institutions.

\section{Results and discussion}

The following discussion situates the selected interview data within the LET trilogy and its implication for inclusive practice.

\section{Pedagogy}

From the comments of both teachers and students at the two institutions, a difference in how online technology was employed is evident. The following comment from one teacher indicates how LMSs in the Chinese institution were used to replicate face-to-face learning situations in his classes - 'I think for the video meeting, well actually for this semester I want to use that function but the problem is as I just mentioned I cannot observe all the students simultaneously, so I just turn off all the video like we are doing now' (China_T4). The comment reveals a level of frustration with conducting classes online. Observing students was an essential part of this teacher's practice which could not be conducted in the same way remotely. Another teacher from the Chinese 
institution explained that students tended to 'copy answers' (as opposed to working through problems) in an online environment when compared to classroom situations - 'If I ask some questions they will always copy, copy the answers, the first students did you know, but I have seen that all my students are so active they can answer me questions so good, you know, but actually most of them just do the copy, copy-paste, copy-paste. That's a bit different when we are in the classroom' (China_T2). The teacher also observed a lack of participation in the online classes. This may suggest that students are frustrated by the limitations and differences of online learning environments. LMSs, for example, are often designed to deliver content in a uniform linear way, which may lead to information overload, disorientation, and a loss in learning efficiency for students who do not fit the delivery style (Bajaj \& Sharma, 2018). Perhaps the lack of engagement also has something to do with the challenges in establishing effective working relationships between teachers and students. Another teacher indicated that 'I'd say I've had to work harder this year to make a relationship with my students but I... I've lost my train of thought...It's not impossible to build rapport now I think. Maybe just a little bit harder' (China_T6). The experience of using technology and learning styles appeared to be less of an issue at the Australian institution. One teacher commented that she observed her students learn more by doing and observing rather than using the written form - 'They can't learn by being told or by written, and without pigeon holing anyone, they typically are kinaesthetic learners and very visual learners' (Australia_T4). The existence of visual learners is also supported by a student reflecting on her learning style at the Australian institution - 'But I'm a very visual learner as well, so for me, I do need to watch it maybe in a different part of a video or a different part of the day' (Australia_S1).

The identification of learning styles raises an interesting question in terms of their relevance to inclusivity. There are many ways to categorise learners. Felder and Henriques (1995) describe learners in four categories: active and reflective learners, sensing and intuitive learners, visual and verbal learners, and sequential and global. However, the efficacy of categorising learners by learning styles is contested by some researchers. Learning style identification may not be a relevant factor in delivering effective education as the way in which learners prefer to learn may not be the best way for them. According to Florian and Spratt (2013), a truly inclusive teaching practice cannot be accomplished by tailoring instruction to most learners; instead, it should seek to extend existing learning opportunities to each person. In other words, each learner should be respected for their individual characteristics. Perhaps, the way forward is to create an environment that enhances learner interaction so that they can determine their own best practice under the guidance of an experienced teacher. As one teacher put it, 'Build communities of students, so that they then can talk together and learn from each other, and motivate each other' (Australia_T10b). Rather than allowing the perceived limitations of online learning systems to dictate particular teaching methods, it may be more efficacious to create an environment where students themselves determine how they want to learn. If we are to be truly inclusive in our teaching practices, labelling students as a particular type of learner may be counterproductive.

\section{Learning Material}

Both curriculum and learning resources are critical components of effective learning environments. The content, curriculum and delivery mechanisms have to engage students in learning and foster interaction to be effective (Stone, 2017). There were several examples of the different types of learning materials provided by teachers at the Australian institution. YouTube featured as an important vehicle to disseminate information. As one student expressed, 'That's why you see such great information on YouTube, because they are passionate about it and they have classes that people find interesting' (Australia_S2). Another teacher mentioned that they regarded LMS resources basically as a library for students to access and complete their written assessment work, 'So right now, it's basically used as like a library where we have a lot of resources sitting there for students to access and they access their written assessment work and the submissions of assessment'(Australia_T6). There is also the issue of what device is used to access online systems. Furthermore, text-only learning materials may not effectively engage learners on certain types of devices. For example, the student who mentioned that YouTube videos were engaging stated that she did not like to read materials from her cell phone and said 'I' $m$ not as much of a fan of reading the materials off my phone because I just find it's - for me it's too - I don't really like reading off my phone' (Australia_S1).

The use of mobile phones to engage with online material is often an issue that is overlooked in LMS design. Certainly, mobile phones lend themselves more effectively to visual and verbal types of knowledge representation rather than the written form. A study by Papadakis et al. (2018) found that student access to Moodle via mobile phones was done only when necessary: many students expressed the need for more userfriendly mobile access, especially for written materials. The view from the Chinese teaching staff was that more familiarisation with online learning tools would help course delivery. One teacher made this explicitly clear in 
her comment by saying 'Some I would... I would try to use some functions of LMS which I had never used before, like uploading the learning material, design some online quizzes' (China_T7). Another teacher stated that the lack of resources for an online environment was a problem and said 'We need ... I think we need to you know, probably put in more efforts to providing more good resources to students and teachers' (China_T4). Just as the example of the student from the Australian institution and her expression of the preference for YouTube videos demonstrates, one student from China mentioned that providing visual information was helpful. The student said 'Our teacher will use it to....show some pictures and knowledge that we can't acquire by other ways'(China_S1).

Issues surrounding the design and dissemination of learning materials are complex and multifaceted. Students interact with online environments in different ways (for example, mobile phones and standard PCs). They often have personal preferences for different types of knowledge representation (such as videos, pictures, sound recordings and artefacts) and frequently struggle to interact with each other in online environments. Teachers, for their part, must have the skills necessary to create and configure learning materials appropriate for their audience. This latter point is important, as a lack of engagement with online learning modalities exposes a skill deficit in teachers when online learning becomes the only mode possible. Institutional support is vital for teachers' professional development, and this theme is addressed in the next section of this paper.

\section{Institution}

Institutional support is of paramount importance for online delivery to be successful. There are two crucial ways that institutions can support their teachers: 1) establishing professional services dedicated to the creation and configuration of learning materials, and 2) providing training opportunities for faculty to develop skills that will allow them to engage with learning environments more effectively. At the Australian institution, one teacher stated that the institution regularly provided instructional design services to teachers- 'I have an instructional designer regularly come onto a team meeting that I run and will regularly present to our team on what's new? What are they doing? What are they developing? How can you do it. So, we're continually improving our product as we go'(Australia_T5).

On the training front, another teacher reflected on the willingness of their institution to provide training services in the form of workshops when necessary-' If we said we want to do that, they would find someone probably within a couple of weeks and have a workshop ready to go '(Australia_T4). Student experiences with training were also positive. For example, one student provided an example of the type of training she was provided to help her access and use Moodle- 'We were guided through the using of these systems. We were told where to go and how to submit assignments and what to look for' (Australia_S3). Another student shared her opinion that the university had a duty of care to provide relevant training-'No. I think it would be amiss not to provide practical (legal things) at the beginning for students'(Australia_S2).

Opinions from the Chinese institution were different. It appeared that resources and support to facilitate online learning were not always available. For example, one teacher commented on the lack of comprehensive courseware for an IT course that was forced to be delivered online- 'Getting the support from the college may be one. Another support as I just now mentioned is that particular comprehensive courseware. As far as I can see that particular comprehensive courseware is not available yet'(China_T5). There were no comments from students from the Chinese institution on the state of institutional support or training provided. This is perhaps because the Chinese institution rarely conducts tailored training programs for students preferring instead to rely on its teaching faculty to provide any necessary training directly. In all fairness to the institution, courses were designed to be delivered in a F2F environment. However, anecdotal evidence would suggest that online delivery is improving.

Institutions are perhaps the most critical element in the triad of factors that contribute to effective inclusive learning spaces. To create an inclusive environment for our students, institutional commitment to improving this environment is crucial, including providing appropriate training opportunities to improve teacher skills (Lawrie et al., 2017). It is insufficient for our institutions to create policies on inclusivity and expect them to be enacted without support. Institutional involvement in enhancing learner inclusivity must be proactive and supportive of the teacher-student relationship in the learning process. This is particularly important for LMS online learning spaces, where institutions have a vital role in ensuring that students are also competent in using real-time communication tools to maintain a sense of community (Turnbull et al., 2021). 


\section{Conclusion}

Increasingly, institutions engaged in vocational training are doing so with a diverse range of learners in a global environment undergoing rapid change. An important principle to observe in successful training delivery is to afford the maximum opportunity to impart knowledge and skills to individual learners that leverage their unique learning characteristics and preferences. This paper presents a snapshot of perspectives of teachers and students from two vocational training institutions embedded in different cultural, political, and language landscapes Australia and China. It was evidenced from the comments and perspectives of the participants that including all stakeholders as partners in the learning process is vital to effective knowledge acquisition. We propose that three elements (pedagogy, learning materials, and institutions) must work together to create inclusive learning spaces. This trilogy of interrelated components intersects through learning management systems that enable multi-modal opportunities to engage students in interactive knowledge exchanges. Although this paper is limited in scope to only two institutions from two countries, we hope that the findings inspire future research into strategies to leverage individual learning attributes in the quest to develop more inclusive practices for students.

\section{References}

An, D., \& Carr, M. (2017). Learning styles theory fails to explain learning and achievement: Recommendations for alternative approaches. Personality and Individual Differences, 116, 410-416.

Bajaj, R., \& Sharma, V. (2018). Smart Education with artificial intelligence based determination of learning styles. Procedia Computer Science, 132, 834-842.

Boghossian, P. (2006). Behaviorism, Constructivism, and Socratic Pedagogy. Educational Philosophy and Theory, 38(6), 713-722. https://doi.org/10.1111/j.1469-5812.2006.00226.x

Chan, E. (2019). Blended Learning Dilemma: Teacher Education in the Confucian Heritage Culture. Australian Journal of Teacher Education, 36-51. https://doi.org/10.14221/ajte.2018v44n1.3

Chugh, R., Ledger, S., \& Shields, R. (2017). Curriculum design for distance education in the tertiary sector. Turkish Online Journal of Distance Education, 18(2), 4-15.

Felder, R. M., \& Henriques, E. R. (1995). Learning and teaching styles in foreign and second language education. Foreign Language Annals, 28(1), 21-31.

Florian, L., \& Spratt, J. (2013). Enacting inclusion: a framework for interrogating inclusive practice. European Journal of Special Needs Education, 28(2), 119-135. https://doi.org/10.1080/08856257.2013.778111

Govindasamy, T. (2001). Successful implementation of e-Learning. The Internet and Higher Education, 4(3-4), 287-299. https://doi.org/10.1016/s1096-7516(01)00071-9

Levin, B. (2000). Journal of Educational Change, 1(2), 155-172. https://doi.org/10.1023/a:1010024225888

Mapuva, J. (2009). Confronting challenges to e-learning in higher education institutions. International Journal of Education and Development using ICT, 5(3), 101-114.

Moriña, A. (2017). Inclusive education in higher education: challenges and opportunities. European Journal of Special Needs Education, 32(1), 3-17. https://doi.org/10.1080/08856257.2016.1254964

Papadakis, S., Kalogiannakis, M., Sifaki, E., \& Vidakis, N. (2018). Access Moodle Using Smart Mobile Phones. A Case Study in a Greek University. In Interactivity, Game Creation, Design, Learning, and Innovation (pp. 376-385). https://doi.org/10.1007/978-3-319-76908-0 36

Stone, C. (2017). Opportunity through online learning: Improving student access, participation and success in higher education. Perth: The National Centre for student equity in higher education (NCSEHE), Curtin University. https://apo.org.au/node/94591

Turnbull, D., Chugh, R., \& Luck, J. (2019). Learning Management Systems: An Overview. Encyclopedia of Education and Information Technologies. https://doi.org/10.1007/978-3-319-60013-0_248-1

Turnbull, D., Chugh, R., \& Luck, J. (2021). Issues in learning management systems implementation: A comparison of research perspectives between Australia and China. Education and Information Technologies. https://doi.org/10.1007/s10639-021-10431-4

Vallis, C., \& Shalavin, C. (2020). Bend me, stretch me: Connecting learning design to choice. 37th International Conference on Innovation, Practice and Research in the Use of Educational Technologies in Tertiary Education (ASCILITE 2020).

Wang, J., Doll, W. J., Deng, X., Park, K., \& Yang, M. G. (2013). The impact of faculty perceived reconfigurability of learning management systems on effective teaching practices. Computers \& Education, 61, 146-157. https://doi.org/10.1016/j.compedu.2012.09.005

Watkins, C., \& Mortimore, P. (1999). Pedagogy: What do we know. Understanding pedagogy and its impact on learning, 1-19, Sage. http://dx.doi.org/10.4135/9781446219454.n1 
Turnbull, D., Chugh, R., \& Luck, J. (2021). Creating an inclusive educational environment for vocational learning: A tale of two cities. In Gregory, S., Warburton, S., \& Schier, M. (Eds.), Back to the Future - ASCILITE '21. Proceedings ASCILITE 2021 in Armidale (pp. 334-339). https://doi.org/10.14742/ascilite2021.0148

Note: All published papers are refereed, having undergone a double-blind peer-review process.

The author(s) assign a Creative Commons by attribution licence enabling others to distribute, remix, tweak, and build upon their work, even commercially, as long as credit is given to the author(s) for the original creation.

(C) Turnbull, D., Chugh, R., \& Luck, J. 2021 